\title{
Pyrexia of unknown origin. Presenting sign of hypothalamic hypopituitarism
}

\author{
R. MARILUS* \\ M.D. \\ S. LEIBA $\dagger$ \\ M.D.
}

A. BARKAN*
M.D.

R. ARIE*

M.D.

\section{Summary}

A 62-year-old man was admitted to hospital 10 times over 12 years because of pyrexia of unknown origin. Hypothalamic hypopituitarism was diagnosed by dynamic tests including clomiphene, LRH, TRH and chlorpromazine stimulation. Lack of ACTH was demonstrated by long and short tetracosactrin tests.

The aetiology of the disorder was believed to be previous encephalitis.

Following substitution therapy with adrenal and gonadal steroids there were no further episodes of fever.

\section{Introduction}

Pyrexia of unknown origin (PUO) may present some of the most challenging problems that the clinician is called upon to solve. Infectious, inflammatory, neoplastic and collagen diseases are the most frequent final diagnoses in these cases (Jacoby and Swartz, 1973). Fever may be the presenting symptom of several, less frequent entities which, if not specifically suspected, may be overlooked.

The authors present the case of a 62-year-old man, whose frequent bouts of fever were undiagnosed for 12 years. The cause of his disease was finally proved to be hypothalamic hypopituitarism.

\section{Case report}

A 62-year-old man was admitted to the Department of Internal Medicine 'B' because of fever of up to $38.5^{\circ} \mathrm{C}$ of one day's duration. There were no complaints concerning the urinary, respiratory or gastrointestinal tracts. The body temperature returned to normal one day after admission, without any specific therapy and remained so throughout his stay in hospital.

In the 12 years before the present admission at least 10 such admissions because of fever of unknown $\stackrel{\vec{\circ}}{\circ}$ origin had been recorded. During this period, he 3 was extensively investigated for possible infectious, $\vec{T}$ neoplastic, inflammatory and collagen diseases, but the various tests failed to reveal the cause of the fever.

A detailed past history of the patient was nom contributory. However, further questioning at $=$ a later period of his admission revealed interestigg? pertinent facts. Twelve years before the present $\frac{\partial}{\circ}$ admission his body hair and sex activity had been⿳亠丷厂 normal. At that time he had an acute febrile illness $\frac{0}{0}$ with severe headache which lasted for about one $\Rightarrow$ week. He was not admitted to hospital and did not? receive any specific therapy.

Following this illness his hair started to fall and he noticed a decline in his sexual activity. In the following years there were recurrent bouts of fever, 3 . sometimes accompanied by episodes of diarrhoea and vomiting, with a picture of dehydration and 3 . lowering of BP which were twice diagnosed as septic and cardiogenic shock. During these episodes steroids were administered and the patient recovered.o Concomitantly a psychiatric disorder developed with auditory hallucinations and paranoidal thinking.

On examination the patient appeared well nourished, his BP was $100 / 70 \mathrm{mmHg}$ and his pulse rate was regular at $80 / \mathrm{min}$. There was no hair on his ${ }_{0}$ chest or axillae, his pubic hair had a feminine configuration, and his testes were hypotrophic $(4 \mathrm{ml}$ vol). No other abnormal physical findings were detected.

A confrontation test revealed a bitemporal hemianopia. Routine laboratory tests which in- 0 cluded total blood count, blood urea nitrogen, creatinine and electrolytes were all in the normal range. 
TABLE 1. Adrenal function. Plasma cortisol and urine 17-ketosteroid (17-KS), 17-hydroxycorticoid (17-OH), and 11-oxy-17-KS (11-OH) responses to tetracosactrin

\begin{tabular}{llccc}
\hline & & Base-line & Short tetracosactrin test & Long tetracosactrin test \\
\hline Plasma & ACTH $(\mathrm{pg} / \mathrm{ml})$ & 0 & & \\
& Cortisol $(\mathrm{nmol} / \mathrm{l})$ & $27 \cdot 6$ & $41 \cdot 4^{*}$ & \\
Urine & $17-\mathrm{KS} \mathrm{mg} / 24 / \mathrm{hr}$ & 0.6 & $3 \cdot 0$ & $0 \cdot 4$ \\
& $17-\mathrm{OH} \mathrm{mg} / 24 / \mathrm{hr}$ & $1 \cdot 3$ & $3 \cdot 5$ & $18 \cdot 5$ \\
& $11-\mathrm{OH} \mu \mathrm{g} / 24 / \mathrm{hr}$ & 9 & & 130 \\
\hline
\end{tabular}

*After 120 and 240 min or tetracosactrin infusion.

Since the physical findings were suggestive of adrenal and gonadal insufficiency, the functions of these glands were investigated basally and upon stimulation.

Tertiary adrenal, gonodal and mild thyroid dysfunction and hyperprolactinaemia were diagnosed (Tables 1, 2, 3). Basal 24-hr urinary steroid excretion, basal plasma cortisol and plasma ACTH levels were all extremely low (Table 1), suggesting the presence of adrenal insufficiency. A tetracosactrin (Synacthen) test $(0 \cdot 25 \mathrm{mg}$ i.v. over $4 \mathrm{hr})$ revealed no increase in plasma and urine steroid levels, suggesting either primary adrenal insufficiency or secondary adrenal atrophy resulting from long-standing absence of trophic action of endogenic ACTH. A long tetracosactrin test $(0.25 \mathrm{mg}$ i.v. over $4 \mathrm{hr}$ for 3 consecutive days) revealed an appropriate rise of urine excretion of corticosteroids, suggesting the presence of adrenal insufficiency of pituitary or hypothalamic origin (Liddle, 1974).

Differentiation between these 2 possibilities is generally accomplished by performing insulin tolerance (ITT) and vasopressin tests (Landon et al., 1966; Eddy, 1968), but these could not be performed because of the presence of electrocardiographic abnormalities indicative of coronary insufficiency.

Basal plasma levels of testosterone $(62 \mathrm{ng} / \mathrm{dl})$ and gonadotrophins (FSH, LH) were low, suggesting the presence of gonadal insufficiency of pituitary or hypothalamic origin (Table 2). Administration of luteinizing hormone-releasing hormone $(\mathrm{LHRH})(100$ $\mu \mathrm{g}$ i.v.) gave an appropriate rise of plasma gonadotrophins, suggesting normal pituitary reserve (Mortimer et al., 1973). Administration of clomiphene, which is believed to be a hypothalamic stimulator of LHRH secretion (Mortimer et al., 1973), failed to produce an adequate rise of gonadotrophin levels (Table 2). The combination of a normal LHRH test and abnormal clomiphene test suggested a hypothalamic lesion as the cause of the hypogonadism in this patient (Mortimer, 1977).

Basal plasma levels of prolactin $(10-23 \mathrm{ng} / \mathrm{ml})$ were found to be above normal.

Hyperprolactinaemia can be the result of one of 2 causes: a hypersecreting pituitary adenoma or a lack of prolactin-inhibiting factor (PIF) reaching the pituitary gland, due to either a hypothalamic lesion or a hypophiseal stalk section (Thorner, 1977). Administration of TRH is believed to stimulate directly the pituitary secretion of prolactin (Jacob et al., 1971). There was increased response to TRH (Table 3), possibly as an expression of increased receptor sensitivity due to lack of PIF. Dopamine is believed to be a PIF (Shaar and Clemens, 1974; Enyalbert, Pria and Korden, 1977). Administration of chlorpromazine, known to be a hypothalamic

TABLE 2. Hypothalamic-pituitary-gonadal axis function. Follicle stimulating hormone (FSH) and luteinizing hormone (LH) responses to LH-releasing hormone (LHRH) and clomiphene

\begin{tabular}{ccc}
\hline $\begin{array}{c}\text { LHRH test }(100 \mu \mathrm{g} \text { i.v.) } \\
\text { Time } \\
\text { (min) }\end{array}$ & $\begin{array}{c}\text { Plasma FSH } \\
\text { (mu./ml) }\end{array}$ & $\begin{array}{c}\text { Plasma LH } \\
\text { (mu./ml) }\end{array}$ \\
\hline 0 & $2 \cdot 3$ & $2 \cdot 2$ \\
15 & $4 \cdot 1$ & $4 \cdot 4$ \\
30 & $4 \cdot 7$ & $5 \cdot 9$ \\
45 & $5 \cdot 0$ & $6 \cdot 4$ \\
60 & $5 \cdot 1$ & $5 \cdot 6$ \\
90 & $5 \cdot 4$ & $5 \cdot 5$ \\
\hline
\end{tabular}

\begin{tabular}{ccc}
$\begin{array}{c}\text { Clomiphene test (200 mg/day for 6 days) } \\
\text { Time }\end{array}$ & $\begin{array}{c}\text { Plasma FSH } \\
\text { (mu./ml) }\end{array}$ & $\begin{array}{c}\text { Plasma LH } \\
\text { (mu./ml) }\end{array}$ \\
\hline Base-line & $2 \cdot 3$ & $2 \cdot 2$ \\
day 2 & $4 \cdot 0$ & $0 \cdot 4$ \\
day 3 & $2 \cdot 4$ & $0 \cdot 5$ \\
day 4 & 0.5 & $0 \cdot 7$ \\
day 6 & 0.8 & $0 \cdot 7$ \\
\hline
\end{tabular}

dopaminergic receptor blocker (Streja, Corenblum and Ezrim, 1978), failed to produce an adequate rise in plasma prolactin levels. The combination of an increased response of prolactin secretion to TRH stimulation and a subnormal response to chlorpromazine suggested a hypothalamic lesion as the cause of the hyperprolactinaemia.

Normal values of $T_{3}, T_{4}$, and TSH $(6.8 \mu \mathrm{g} / \mathrm{ml}$ and $1.7 \mu \mathrm{u} . / \mathrm{ml}$ ) suggested a normal hypothalamicpituitary thyroidal axis but cannot be taken as final proof (Snyder et al., 1974). Administration of TRH, 
which is believed to stimulate the pituitary to secrete TSH, showed a delayed peak (Table 3), thus confirming impairment of TSH secretion of hypothalamic origin (Faglia et al., 1973).

\section{Discussion}

Endocrinological investigation pointed to a hypothalamic lesion as being the cause of the abnormal function of the pituitary, concerning the secretion of gonadotrophins, prolactin and TSH. Adrenal insufficiency was proved but the patient's condition made it technically impossible to determine whether it was hypothalamic or pituitary in origin.

TABLE 3. Plasma prolactin and TSH responses to TRH and chlorpromazine (Baseline: $10-23 \mathrm{ng} / \mathrm{ml}$; TSH $=1.7 \mu \mathrm{u} . / \mathrm{ml}$; $\mathrm{T}_{4}=6.8 \mu \mathrm{g} / \mathrm{ml}$ )

\begin{tabular}{ccc}
\hline $\begin{array}{c}\text { TRH test }(200 \mu \mathrm{g} \text { i.v. }) \\
\text { Time } \\
(\mathrm{min})\end{array}$ & $\begin{array}{c}\text { Plasma prolactin } \\
(\mathrm{ng} / \mathrm{ml})\end{array}$ & $\begin{array}{c}\text { Plasma TSH } \\
(\mu \mathrm{u} . / \mathrm{ml})\end{array}$ \\
\hline 0 & 10 & $1 \cdot 7$ \\
15 & 70 & $4 \cdot 2$ \\
30 & 30 & $5 \cdot 4$ \\
45 & - & $6 \cdot 9$ \\
60 & 25 & $4 \cdot 6$ \\
\hline
\end{tabular}

Chlorpromazine test (25 g i.m.)

Time Plasma prolactin

(min) $\quad(\mathrm{ng} / \mathrm{ml})$

\begin{tabular}{rl}
$(\mathrm{min})$ & $(\mathrm{ng} / \mathrm{ml})$ \\
\hline 0 & 13 \\
30 & $14 \cdot 5$ \\
60 & 15 \\
\hline
\end{tabular}

Hypothalamic lesions leading to endocrinological deficits may be tumours, trauma, irradiation, granulomatous, vascular, degenerative, and inflammatory diseases (Daniel and Treip, 1977). A suprasellar space-occupying lesion was ruled out by the normal protein level of the CSF (Kahana et al., 1962), normal X-rays of the skull, and normal computerized tomography of the sella, suprasellar and ventricular areas. No history of trauma or irradiation to the head was obtained, and there were no clinical or laboratory findings suggestive of a degenerative or granulomatous disease.

On further questioning the patient revealed that episodes of fever and the loss of hair and libido actually started about 12 years before the present admission, soon after an acute illness which lasted for a few days. This detail might suggest a past history of encephalitis as a possible cause of the hypothalamic lesion. The findings of symmetrical damage of the optic nerves and the severe diffuse atrophy of the cortex lend further support to this assumption.

Recurrent episodes of fever, defects in visual fields, endocrinological deficits of hypothalamic origin, $\stackrel{2}{\gtrless}$ hypersomnia and severe mental disturbances were all found in the patient. These findings may be attributed $c$ to what has been described in the literature as the diencephalic syndrome (Bower, 1954).

Substitution therapy with $7.5 \mathrm{mg}$ prednisone/day응 and injections of testosterone enanthate $250 \mathrm{mg} / \underline{\underline{\underline{\sigma}}}$ month was started. During 16 months of follow-up there were no more episodes of fever, hypersomnia $\stackrel{\varnothing}{\varrho}$ disappeared, and vigour and libido reappeared. This amelioration on substitution therapy suggests that the adrenal and gonadal insufficiencies were the ${ }^{\circ}$ cause of the above-mentioned symptoms, and that $\vec{\omega}$ these were not due to a lesion of the hypothalamico centres of temperature and alertness, thus excludingo the diagnosis of diencephalic syndrome. The mental 3 . disorder was probably the result of the severe cortex $r y$ atrophy, a sequel of the encephalitis and/or of long-is standing and irreversible adrenal insufficiency (Parker, Isaacs and McKerron, 1976).

Endocrinological deficits due to encephalitis $\vec{\circ}$ affecting the hypothalamus have been reported in a응 small number of cases and are generally found in children or in the second or third decades of life (Pai et al., 1976; Haston, Winternitz and Howieson, 1969; Fenton and Kleinman, 1974). In a review of $60 \overrightarrow{0}$ cases of such hypothalamic lesions the oldest caso.. was 30 years old (Bower, 1954). In the present case, the diagnosis was made when the patient was years old, the disease having begun at the age of 50 years. The form of presentation with PUO and the recurrent episodes of severe shock of unknown cause $\bar{\Phi}$ which were diagnosed as septic and cardiogenic $\stackrel{\varrho}{\Rightarrow}$ were undoubtedly an expression of chronic adrenal insufficiency with exacerbations.

The long history of fever in this patient emphasizes the necessity of endocrinological investigation in cases of pyrexia of unknown origin in which other, $\frac{0}{3}$ more common, causes have been ruled out.

\section{References}

Bower, H.G. (1954) Endocrine and other clinical manifestations of hypothalamic disease. Journal of Clinical 윽 Endocrinology and Metabolism. 14, 13.

DANIEL, P.M. \& TREIP, C.S. (1977) The pathology of the $\frac{7}{2}$ hypothalamus. Clinics in Endocrinology and Metabolism, 6, 3.

EDDY, R.L. (1968) Aqueous vasopressin provocative test of anterior pituitary function. Journal of Clinical Endocrin- $N$ ology, 28, 1836.

Enyalbert, A., Pria, M. \& Korden, C. (1977) Dopamine free prolactin inhibiting factor (PIF) in rat hypothalamic extract. European Journal of Pharmacology, 41, 243.

Faglia, C., Beck-Peccoz, P., Ferrari, C., Travaglino, $\frac{c}{\mathbb{C}}$

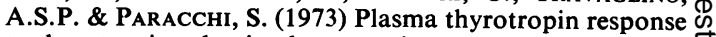
to thyrotropin-releasing hormone in patients with pituitary and hypothalamic disorders. Journal of Clinical Endocrinology and Metabolism, 37, 595.

Fenton, L.J. \& KLeInman, L.I. (1974) Transient diabetes insipidus in a newborn infant. Journal of Pediatrics, 85, 79. 
Haston, R.H.A., Winternitz, W.W. \& Howieson, J.K.Y.L. (1969) Selective hypopituitarism following tuberculous meningitis. American Journal of Diseases of Children, 118, 903.

JACOB, L.S., SNyder, P.J., Wilber, J.F., Utiger, R.D. \& DAUGHADAY, W.H. (1971) Increased serum prolactin after administration of synthetic thyrotropin releasing hormone (TRH) in man. Journal of Clinical Endocrinology and Metabolism, 33, 996.

JACOBY, G.A. \& SWARTZ, M.N. (1973) Fever of undetermined origin. New England Journal of Medicine, 289, 1407.

Kahana, L., Lebovitz, H., Lusk, W., McPherson, H.T., Davidson, E.T., OPPENHEIMER, J.H., ENGEL, F.L., Woodhall, B. \& ODOM, C. (1962) Endocrine manifestations of intracranial extrasellar lesion. Journal of Clinical Endocrinology and Metabolism, 22, 304.

Landon, J.L., Greenwood, F.C., StamP, T.C.B. \& Wynn, V. (1966) The plasma sugar, free fatty acid cortisol and growth hormone response to insulin and comparison of this procedure with other tests of pituitary and adrenal function. II. In patients with hypothalamic or pituitary dysfunction or anorexia nervosa. Journal of Clinical Investigation, 45, 437.

LidDle, G.W. (1974) The adrenal-cortex. In: Textbook of Endocrinology (Ed by Williams, R.H.), pp. 233-283. W. B. Saunders Co., Philadelphia, London, Toronto.

Mortimer, C.H., Besser, G.M., McNeilly, A.S., Marshal,
J.C., Harsoulis, P., Tunbridge, W.M.G., Gomez-Pan, A. \& HALL, R. (1973) The LH and FSH releasing hormone test in patients with hypothalamic-pituitary-gonadal dysfunction. British Medical Journal, 4, 73.

Mortimer, C.H. (1977) Clinical applications of the gonadotrophin releasing hormone. Clinics in Endocrinology and Metabolism, 6, 167.

Pai, K.G., Rubin, H.M., Wedemyer, P.P. \& Linarelli, L.G. (1976) Hypothalamic-pituitary dysfunction following group B beta hemolylic streptococcal meningitis in a neonate. Journal of Pediatrics, 88, 289.

PARKer, R.R., IsAaCs, A.D. \& MCKerron, C.G. (1976) Recoverable organic psychosis after hypopituitary coma. British Medical Journal, 1, 132.

ShaAR, C.J. \& Clemens, J.A. (1974) The role of catecholamines in the release of anterior pituitary prolactin in vitro. Endocrinology, 95, 1202.

SNyder, P.J.L.S., Jacobes, M.M., Robello, F.H., Sterling, F.H., Shore, R.N., Utiger, R.D. \& Daughaday, W.H. (1974) Diagnostic value of TRH in activity and hypothalamic disease. Annals of Internal Medicine, 81, 751.

Streja, D., Corenblum, T.B. \& Ezrim, C. (1978) Hypothalamic hypopituitarism presenting as gallactorrhea-amenorrhea. Journal of the American Medical Association, 239, 1783.

Thorner, M.O. (1977) Prolactin. Clinics in Endocrinology and Metabolism, 6, 201. 